\title{
Gazete Manşetlerinin İnşasında İdeolojik Konumlanışın İzleri: Covıd-19 ile İlgili Manşetlerin Söylem Analizi
}

\author{
Saniye VATANDAŞ
}

$\ddot{\mathrm{O} z}$

Modern zamanların önemli kavramlarından birisi olan ideoloji, en genel manasıyla, varlığ1 ve hayatı değerlendiriş tarzını ifade etmektedir. Bu yönüyle ontolojik, epistemolojik ve değerler sistemini kapsayan bir dünya görüşü olarak anlam kazanmaktadır. Ayrıca sosyo-politik açıdan iktidara ve iktidarın uygulamalarına ilişkindir. Böyle olunca hem iktidar uygulamalarının meşruiyetinin hem de söz konusu uygulamalara itirazın gerekçelerinin en önemli referansı ideolojik kabullerdir. Bu bağlamda düşünüldügünde kitle iletişim araçları genel olarak yayın politikalarında, özel olarak da iktidarın uygulamalarına yönelik konumlanışlarında ideolojik bir duruşu temsil ederler. Bu araştırma, COVID-19 salgınına ilişkin ülke düzeyinde gerçekleştirilen önlem ve uygulamalar örneği üzerinden gazetelerin ideolojik konumlanışlarını konu edinmektedir. Araştırma kapsamında 10 Mart 2020 gününü takiben tüm Türkiye’nin gündemine gelen; bireysel ve toplumsal boyutuyla alışılagelmiş yaşam tarzlarını ve alışkanlıkları temelden etkileyen COVID-19 salgını kapsamında sosyo-politik karar ve uygulamaların değerlendiriş tarzı incelenecektir. Araştırmanın örneklem grubunu, günlük baskı sayısının \%97'sini temsil eden 15 farklı gazete oluşturmaktadır. Bu gazetelerin COVID-19 salgınının ilk on günündeki birinci sayfa haberleri söylem analizi yöntemiyle çözümlenmiştir.

Anahtar Kelimeler: Covid-19, Gazete, İdeoloji, Söylem analizi

\section{Ideological Differences in the Construction of Newspaper Cuffs: Signal Analysis of} Covid-19 Cuffs

\section{Abstract}

Ideology, which is one of the important concepts in modern times, expresses the way it evaluates existence and life in the general sense. In this respect, it becomes significant as a world view covering the system of ontology, epistemology and values. It is also related to the political power and practices of power from the socio-political viewpoint. Thus, ideological assumptions are the most important reference for both the legitimacy of the practices of power and the rationale behind objection to those practices. When considered in this context, mass media represent an ideological stance in broadcasting policies in general, and their positioning related to the practices of the political power in particular. This research focuses on the ideological positioning of the newspapers based on the example of country-level measures and practices related to the COVID-19 pandemic. The evaluation style of socio-political decisions and practices within the scope of the COVID-19 pandemic, which became a current issue in Turkey on March 10, 2020 and which affected the traditional lifestyles and habits of the individuals and society, will be examined in this research. The sample group of the research consists of 15 different newspapers representing $97 \%$ of the daily circulation. The front-page news of those newspapers during the first ten days of the COVID-19 pandemic was analyzed through discourse analysis.

Key Words: Covid-19, Newspaper, Ideology, Discourse analysis

\section{Atıf İçin / Please Cite As:}

Vatandaş, S. (2021). Gazete manşetlerinin inşasında ideolojik konumlanışın izleri: Covıd-19 ile ilgili manşetlerin söylem analizi. Manas Sosyal Araştrmalar Dergisi, 10(1), 407-421.

Geliş Tarihi / Received Date: 20.05.2020

Kabul Tarihi / Accepted Date: 12.11.2020

\footnotetext{
1 Öğr. Gör. Dr. - Isparta Uygulamalı Bilimler Üniversitesi, saniyevatandas@isparta.edu.tr 


\section{Giriş}

İnsan, üyesi olduğu toplumda ve dünyada neler olup bittiğini bilmek ister. Bu isteğin kitlesel düzeyde gerçekleşmesinin en önemli aracı kitle iletişim araçlarıdır. Bilimsel ve teknolojik gelişmenin kitle iletişim araçlarının işlevinde gerçekleştirdiği hız ve ilerleme sayesinde insanın bilgilenme ihtiyacı çok farklı kanallardan ve olabildiğince hızlı bir şekilde gerçekleşme düzeyine erişmiştir. Okuyucu, dinleyici ve izleyici konumundaki bireyler teknolojik gelişmenin bugün ulaştığı aşamada, bilmek istediklerine neredeyse anında ulaşma imkânı elde edebilmektedirler. Üstelik bunun maliyeti çok ucuzlamış, erişim hızı müthiş artmıştır. Fakat kitle iletişim araçlarının yaygınlığı ve hızı, özellikle de parçası oldukları ekonomi-politiğin etkisi, salt bilgi vermenin ötesine geçip farklı işlevler üstlenmelerini de sağlamışır. Kitle iletişim araçları artık sadece bilgi vermekle kalmamakta, parçası oldukları ekonomi-politik adına "ikna etme", "riza oluşturma" işlevlerini de üstlenmiş bulunmaktalar; hatta bu işlevleri birçok bakımdan asıl olmuştur.

Kuramsal açıdan değerlendirildiğinde kitle iletişim araçlarının, bilgi ve haber verme, eğlendirme, eğitme, kamuoyu oluşturma, kamuoyu adına iktidarı denetleme gibi işlevleri vardır. "İkna etme" ve "rıza oluşturma" tüm bu işlevlere eklemlenmiş bir şekilde işlemektedir. Kitle iletişim araçlarının yerel, ulusal veya küresel "iktidarlar" ile olan ilişkileri karşılıklı birbirlerine meşruiyet sağlamalarına imkân sunmakta, kitle iletişim araçları bu bağlamda özelde birey, genelde kitle üzerinde belirgin bir nüfuza ulaşmaktadır. Ancak örtük olmayan söz konusu ilişki ve işlevler kitleler tarafindan genellikle görülmemekte veya görülmek istenmemektedir. Bu durumu şöyle ifade etmek yanlış olmayacaktır: Kralın çıplak olduğunu herkes görüyor fakat hiç kimse "çıplak" olduğunu söylemek istemiyor; hatta tam aksine, olmayan elbisesinin güzelliğinden söz etmek tercih ediliyor. Bu tespitimizin en önemli dayanağı, kitle iletişim araçlarının özellikle kamuoyu adına veya kamuoyuna yönelik işlevlerinde objektif kaldıklarına ve meslek ahlâk1 çerçevesinde hareket ettiklerine ilişkin bir kanaatin yaygın mevcudiyetidir. Fakat alana ilişskin yapılmış çok sayıdaki araştırma, kitle iletişim araçlarının yalnızca bilgi/haber aktaran kaynaklar olmadığını; aynı zamanda, iktidar karşısındaki konumlanışlarıyla örneğin siyasal sistemin ve ekonomik ilişkilerin içinde aktif rol aldıklarını ortaya koymuştur. "İkna" ve "rıza" inşası bu aşamada devreye girmekte ve önemli işlevler yerine getirmektedir. Zira kitle iletişim araçları, sahip oldukları dinamik ve son derece gelişmiş teknolojik alt yapıyı kullanarak kitleye sundukları mesajı önceden belirlenmiş amaçlar doğrultusunda belli stratejik yöntemlerle biçimlendirip paketleyerek kitleye sunmaktadırlar. Hedef kitleye sunulan haberler sadece bilgilendirme amacina hizmet etmemekte, daha çok ve hatta öncelikle kitlenin belli bir düşünce formuna sokulması hedeflenmektedir.

Bu araştırma Aralık-2019 itibarıla dünya kamuoyunun gündemine gelen ve kısa sürede tüm ülkelerin özel problemi olan COVID-19 salgını ile ilgilidir. İlk vakanın görüldüğü 10 Mart 2020 günü itibarılyla COVID-19 salgını kitle iletişim araçlarının üzerinden Türkiye'nin en önemli ve hatta tek gündemi haline geldi. Bu makalenin yazıldığ1 Mayıs-2020 günlerinde de bu özelliğini sürdürmekteydi. COVID-19, toplamda on binlerce insanın öldüğü ve günlük ölümlerin binlere ulaştığı Çin, İran, İtalya, İspanya, ABD örneklerinden hareketle, Türkiye'nin gündemi olmadan önceki günlerde ve hatta aylarda kitle iletişim araçlarının haberleri arasında yer almaktaydı. Salgının Türkiye’ye sıçraması bekleniyor, bu sebeple mümkün olduğunca bu sıçramayı ötelemenin ve muhtemel yayılma hızını düşürmenin tedbirleri alınıyordu. Başta devlet kurum ve kuruluşları olmak üzere resmi veya sivil inisiyatif, salgına karşı tedbir almanın çabasını yoğun bir şekilde yürütüyordu. Tedbirlerin yaygınlığ1 ve kapsamı açısından devlet kurum ve kuruluşları beklendiği gibi önde ve sürecin belirleyicisi konumunda idiler. İstenmeyen fakat geleceği kesin olan durumla 10 Mart günü karşılaşıldı ve resmi olarak ilk vaka tespit edildi. Böylelikle COVID-19 salgını kitle iletişim araçlarının tek gündemi oldu. Bu gündem içerisinde kitle iletişim araçlarının COVID-19 salgınını haber etmenin ötesinde, salgin konusunda kitleleri bilgilendirme ve bilinçlendirme işlevini de üstlendikleri gözlendi. Tehlikenin büyüklügü hakkında uyarıda bulunma, alınması gereken tedbirler konusunda bilgi verme işlevlerini yoğun bir şekilde yerine getirdiler. Fakat tüm bunları yaparken sürecin inisiyatif sahibi konumundaki siyasal iktidarın uygulamalarına karşı da konumlarını belirleyip, destek veya eleştiri işlevlerini yerine getirmenin çabası içerisinde oldular.

Bu araştırma Türkiye'deki ulusal gazetelerin COVID-19 salgınının ilk on günündeki manşetleri üzerinden yürütülmüştür. Gündemin en sıcak günlerinde gazetelerin iktidarın uygulamalarına yönelik destek ve/veya eleştiri işlevini yerine getirirken sahip oldukları söylemler üzerinden ideolojik konumlanmaları belirlenmeye çalsşılmışır. Bu amaçla 11-20 Mart 2020 tarihlerindeki 15 ulusal gazetenin birinci sayfa haberleri incelenmiștir. Örneklemi eden gazeteler Takvim, Karar, Yeni Asir, Yeni Birlike, Türkiye, Yeni Akit, Cumburiyet, Yeni Şafak, Akşam, Sözzü, Sabah, Hürriyet, Milliyet, Posta ve Korkusuz isimli ulusal gazetelerdir. 


\section{Yöntem}

Bu araştırma 2020 yılının ilk aylarından itibaren tüm dünyayı derinden etkileyen COVID-19 salgını (pandemisi) ile ilgili gazete haberlerinin söylem analizini konu edinmektedir. Söylem analizi aracilığyla gazetelerin COVID-19'a ilişkin haberleri üzerinden iktidar karşısındaki ideolojik konumlanışlarını, bu konumlanışa bağlı olarak söylemlerini dile getiriş tarzlarını belirlemek amaçlanmıştır. Zira gazeteler COVID-19 salgını nedeniyle farklı birçok önlem ve kısıtlamalara yönelen siyasal iktidarın uygulamalarını sadece "haber" etmenin ötesinde, tüm benzer durumlarda olduğu üzere, iktidar ile ilişkilerinde ideolojik olarak konumlanarak okurlarını da bu konumlanışı kabullenmenin ve buna göre bir tutum sergilemenin söylemini inşa etmektedirler. Araştırma 11-20 Mart 2020 tarihlerindeki 15 ulusal gazetenin birinci sayfa haberleri üzerinden gerçekleştirilmiştir. Tarihin belirlenmesinde, ilk COVID-19 vakasının Türkiye'de 10 Mart günün tespit edilmesi belirleyici olmuştur. Bu ilk vakaya bağlı olarak gazeteler 11 Mart günü COVID19’u çoğunlukla manşetten gündemlerine almışlardır. Dolayısıyla bu araştırma COVID-19 salgınının gazetelerde gündem olduğu ilk on günü kapsamaktadır. Örneklem grubu teşkil eden gazeteler Takvim, Karar, Yeni Asır, Yeni Birlike, Türkiye, Yeni Akit, Cumburiyet, Yeni Şafak, Akşam, Sözcü̈, Sabab, Hürriyet, Milliyet, Posta ve Korkusuz isimli ulusal gazetelerdir. Araştırmanın örneklemini teşkil eden bu gazetelerin 15 Mart 2020 günü toplam tirajlar1 1.736.111'dir (http://gazetetirajlari.com/HaftalikTirajlar.aspx). Türkiye'deki ulusal gazetelerin günlük toplam tirajı ise 1.800 .000 civarındadır. Dolayısıyla örneklemi teşkil eden 15 gazetenin tirajı aynı tarihteki tüm ulusal gazetelerin toplam tirajının \%97’sini oluşturmaktadır.

\section{Literatür Araştırması}

\section{Haber ve Söylem Analizi}

Haberin en bilinen tanımlarından birisi, "belirli bir zamanda meydana gelen ve çok sayıda kişiyi ilgilendiren önemli olayların, doğru ve tarafsız bir şekilde, en kısa zamanda verilmesidir" (Uyguç ve Genç, 1998, s.108, 109) şeklindedir. Yaygın kabule göre kitle iletişim araçlarının temel faktörünü "haber", işlevini ise "haberdar etmek" oluşturmaktadır. Fakat bu ifadeden anlaşıldığı şekliyle sürecin işleyişi basit, açık ve düz değildir. Sürecin işleyişinin özel ve karmaşık bir yapısı vardır. Öncelikle "haber" olan şeyin ne olduğuna karar vermek ve sonra o haber üzerinden amaca ulaşmanın mekanizmalarını işletmek gerekmektedir. Bütün bunların amacı, "haber" üzerinden kitleleri, benzer durumları nasıl görmeleri gerektiğine "ikna" edip; olay ve olguları "görme", "anlama", "değerlendirme" ve "okuma" şablonu sunmaktır. Haberi önemli kılan metninin içeriğidir. Bu içerik bir söylemi dile getirir. Bir başka ifadeyle her haber metni bir söyleme sahiptir. Dolayısıyla kitle iletişim araçlarının hedef kitleye sunduğu haberler sadece bilgilendirme amacına hizmet etmemekte, aynı zamanda kitleyi ikna etme ve ikna ile birlikte kitleyi belli bir düşünce formuna sokmayı hedeflemektedir. Bu nedenle Oskay'ın gazete örneği üzerinden kitle iletişim araçlarınca sunulan haber için dile getirdiği tespit oldukça önemlidir: "Okuduğumuz her haber, onlarca kişinin belirli bir iş bölümü içinde oluşturduğu bir üründür. Endüstriyel bir üründür. Bilinç endüstrisinin endüstriyel bir ürünüdür” (Oskay, 2014, s. 53).

Herman ve Chomsky haber tanımlarında, kitle iletişim araçlarının işlevlerini bireyleri eğlendirmenin, bilgilendirmenin yanında, toplumun kurumsal yapısıyla bütünleştirecek değerleri, inançları ve davranış biçimlerini onlara aşılamak olduğunu belirtmişlerdir (1998, s. 21). Haberde, metnin içeriğini ve dolayısıyla (ideolojik) söylemini tespit edebilmenin farklı teknikleri vardır. "Söylem analizi" bunlardan birisi ve iletişimciler arasında en yaygın olarak kullanılan tekniklerden birisidir. "Söylem analizi, geçmiş dönemlere ait söylenmiş sözleri, müzakerelerde kullanılan dili, belgelere aktarılan kavramları ve deyimleri, kültürel, siyasi ve sosyal bağlam içinde ele alan bir analiz biçimidir" (Balc1, 2013, s. 195). Haberin söylemi belirli ideolojik unsurlarla inşa olunur ve metin üzerinden muhatabı ikna etme amacı taşır. Bu yönüyle söylem, haberi şekillendiren ve metnin kendisinden daha önemli olan unsurdur. Bu bağlamda vanDijk'in örnek sunan tespiti özel bir önem ifade etmektedir. Van Dijk'e göre ideolojilerin söylem yoluyla ifade edilmesi ve yeniden üretilmesi, yalnızca yazılan veya konuşulan olayların ve durumların altında yatan zihinsel modeller tarafindan kontrol edilmez. Öğrencilerine sınıfta konuşan bir öğretmen, diğer milletvekillerine seslenen bir politikacı ya da haber metni yazan bir gazeteci gibi gerçekleşen birçok iletişimsel durumda zihinsel modeller hep devrededir. Bu modeller söylem bağlamını tanımladığından, onlara bağlam modelleri denmektedir (vanDijk, 2015, s. 6).

Haber metnini çözümleme tekniklerinden birisi olan söylem analizi, kitle iletişim araçlarının kullanılma sıklığının artmasıyla yaygınlaşmışıı. Özellikle kitlelerin kitle iletişim araçları ile etki altına alınmasıyla birlikte söylem analizi tekniği daha çok kullanılmaya başlamıstır. Söz konusu teknikte sayısal 
değil niteliksel bir çözümleme yapılmaktadır (Aziz, 2013, s. 145). Haber metninin dayanağı olan söylem her ne kadar farklı yaklaşımlara dayanıyor olsa da Sözen'e göre (1999, s.19) söylem; bir meta, bir eylem; güç ve gücün eyleme dönüşen dil pratiklerine ilişkin süreçtir. Bir başka söyleyişle "söylem" aslında, bir kuruma veya metne anlam veren sistematik olarak düzenlenmiş ifadelerdir (Devran, 2010, s.56). Söylem çözümlemesiyle metin yapıları incelemekle sınırlı kalmayıp anlamlar, fikirler ve ideolojiler açığa çıkarılmaya çalıșilır.

Söylem analizi, çözümlemesi az sayıda metin üzerinde ayrıntılı ve derin bir inceleme yapma imkânı sunmaktadır. Bu çözümleme yöntemi aslında medyanın gerçeği nasıl konumlandırdığı açısından ciddi bir önem taşımaktadır. Bu sınıflandırma dil ile yapılmaktadır. Dil, taraflı olduğu için söylemlerin kullanımında sözcüklerin taşıdığı anlamlar ön plana çıkmaktadır. Haber söylemi üzerine çalışan önemli isimlerden biri olan vanDijk, okuyucunun haberi anlama, inanç oluşturma gibi süreçlerin haber metninin yapisal oluşumuna bağlı olduğunu ve bu süreçlerin haber üretimini gerçekleştirenler tarafindan belirlendiğini ifade etmiştir. Bu açıdan söylem analizi üzerine çalışmalarını yürüten düşünür; güç, erişim, etki, anlama, model, bilgi, tutum ve ideoloji kavramlarına sıkça atıfta bulunmuştur. Van Dijk'e göre; dil kullanımı ve söylem, ideolojileri edinmeyi, öğrenmeyi ve değiştirmeyi de etkileyen en önemli toplumsal pratiklerden birisidir. Çünkü söylemlerimizin çoğu, özellikle de bir grubun üyesi olarak yaptığımız konuşmalar, hep ideolojik temelli görüşlerimizi ifade etmektedir (vanDijk, 2003).

Söylemin, ideolojilerin yeniden üretilmesinde ve günlük ifadelerde çok önemli bir rol oynadığını belirten vanDijk, geliştirdiği analiz yöntemiyle ideolojilerin söylemde nasıl ifade edildiğini ya da nasıl gizlendiğini göstermeye çalışıştır. Van Dijk, haberi, kamu söyleminin bir formu olarak kabul etmektedir. Van Dijk, haber anlatısın "sentaktik" ve "semantik" olmak üzere iki ayrı dilsel çözümleme biçimi olarak ele almıştır. Haber sentaksı, kullanılan cümlelerin gramatik yapıları ile ilgilidir. Semantik ise, sözcüklerin, cümlelerin ve dolayısıyla bütün söylemin anlamına yöneliktir. Van Dijk'in söylem çözümlemesi makro ve mikro yapının ayrı ayrı değerlendirildiği iki bölümden oluşmaktadır. Makro yapıda haber başlıkları, haber girişleri, spotlar ve fotoğraflar tematik yap1 çerçevesinde değerlendirilirken; şematik yapıda ise olayın durumu ve yorumu çözümlenmektedir. Çözümlemenin diğer bölümü olan mikro yapıda ise; sentaktik çözümleme, bölgesel uyum, sözcük seçimleri, haber retoriği çözümlemeleri yapılmaktadır (Özer, 2001, s. 83-84).

\section{Haber ve İnşa}

Kitle iletişim araçları tarafindan kitlelere sunulan haberlerin türü, dili, üslûbu, sunum şekli oldukça sistematik ve özel çaba gerektiren titiz bir çalışma sürecinin ürünüdür. Haberin belirlenmesinden sunuluşuna kadarki sürecin şekillenmesinde, haberi yazanın ve/veya biçimlendirenin ideolojisi, kişiliği, tutumu, inanc1, tercihleri, eğilimleri, ilgileri, yeteneği, mesleki formasyonu, mesleki bilgi ve deneyimi belirleyici olmaktadır. Esasen haber metni tüm bunların ürünüdür. Bu bağlamda "dolayımlama" özel bir önem kazanmaktadır. Dolayımlama, haber içeriğini oluşturan metinlerle, tüketici (izleyici, okuyucu, dinleyici) arasındaki irtibatı kuran bağdır. Dolayımlama ile haber metninin içeriği hem kitle iletişim aracına hem de tüketicisine uygun hale getirilir (Rigel, 2000, s. 179). Dolayımla olumlu veya olumsuz bağlamda anlamlandırılabilmektedir. Olumsuz anlamıyla, toplumsal gerçekliğin kılık değiştirmesini ifade ederken, olumlu anlamıyla toplumsal gerçekliğin "çarpıtılması" yerine, varlı̆̆ın ve bilincin farklı türleri arasındaki tüm etkin ilişkileri ifade etmektedir (Üşür, 1997, s. 123). Fakat anlaşıldığ1 üzere her iki durumda da "gerçeğin" değiştirilip, dönüştürülmesi vardır. Dolayımlamayı iletişim sürecine dâhil olan bir aracın mantık ve biçiminin etkisi olarak tanımlayan Altheide ve Snow, araçların mantık ve biçimlerinin toplumsal etkileşimi dolayımladığını, tanımladığını ve yönettiğini öne sürmüşlerdir (Mutlu, 1995, s. 100). Bu bağlamda Güz'ün de dikkat çektiği üzere (2005, s. 79), muhabir dahil haber metnini yazan veya şekillendiren kişilerin tercih ettikleri, mensubu oldukları, adına hareket ettikleri siyasal, sosyal, kültürel ve psikolojik özelliklerden sıyrilarak, gerçekleşmiş olayı hedef kitleye mekanik bir varlık gibi sunabilmeleri mümkün değildir. $\mathrm{Bu}$ nedenledir ki haber metnindeki "işaretler ve şifreler değer yargiları içerir, yansız değildir. İdeolojik, sosyal, ekonomik, kültürel ve siyasal pozisyonlardan bağımsız anlam verme diye bir şey yoktur" (Erdoğan, 2005, s. 233). Üstelik çoğu zaman kitle iletişim araçlarının hedef kitleye sunduğu haberler sadece bilgilendirme amacına hizmet etmemekte, aynı zamanda kitleyi ikna etme ve ikna ile birlikte belirlenmiş bir şeylere "rıza" göstermelerini sağlamak için kitleyi belli bir düşünce formuna sokmak hedeflemektedir. Bu itibarla kitle iletişim araçları belli birtakım ideolojiler doğrultusunda haber sunumu gerçekleştirdikleri bilinse bile, çoğu zaman okuyucu tarafindan haberlerin ardındaki ideolojik perspektif dikkate alınmaz ve sunulan haber enformasyon olarak kabul edilir. Kitle iletişim araçlarınca sunulan haberlerin süzgeçlenmeden enformasyon olarak kabul edilmesi ile de haber kaynağının hedeflediği manipülasyon ve zihin yaratılması 
süreci sağlanmış olmaktadır. İște, tam da bu noktada yönlendirme ve haberli yönlendirme kavramları devreye girmektedir. Güz'ün tanımına göre yönlendirme "çeşitli yöntemler kullanılarak bireyin düşünce, tutum ve davranışlarının değiştirilmesi" olarak tanımlanmaktadır. Haberli yönlendirme ise, "kitle iletişim aracının yöneticileri haberlerin yaratılması, işlenmesi, rafine edilmesi ve bunların önem derecesine göre sıralanmasını sağlayarak hedef kitlenin inançlarını, tutumlarını ve davranışlarını etkilemeye çalışması" (Güz, 2005, s. 160) olarak tanımlanmaktadır. Kitle iletişim araçları bunu, Chomsky'nin tespitiyle ifade etmek gerekirse, "kaba, net ve doğrudan yöntemler" yerine "ince ve rafine yöntemler" ile gerçekleştirmektedir (Chomsky, 2012, s. 159). Kitle iletişim araçlarının ideolojik konumlanışlarıla ilgili olarak İrvan'ın tespit ve görüşü manidardır: "Medyanın ideolojik olduğu iddiası, onun anlamın toplumsal inşası alanında iş gördüğunnü söylemektir. Medya, üzerinde insanların kendi dünyalarının bilincine vardıkları alanı sağlar. Temizleyici sibernetik donanımlarıly, sterilize edilmiş enformasyon terimi, tüm yinelemeleri ve büyüsüyle, medyanın kültürel boyutları içerisindeki temelde kirli, göstergebilimsel, anlambilimsel, söylemsel niteliğini silemez ya da yok edemez. Kısaca, bunu önlemenin bir yolu yoktur" (İrvan, 2014).

Kitle iletişim araçları için "haber" demek, "söylem" demektir. Söylem, toplumdaki ideolojik gücün iletişimsel boyutudur. Söylem yoluyla, insanlar iktidarı nasıl elde edeceklerini, koruyacaklarını ya da kabul edeceklerini ve hatta daha önemlisi "iktidarı meşrulaştıran" ideolojik olarak çerçeveli sosyal bilişleri öğrenirler. Bu nedenle, belki de diğer eylem biçimlerinden daha somut olarak muhtemelen daha etkili ve daha hızlı olan sosyal grup üyeleri, sosyal yapı hakkında, sosyal yapıdaki konumları ve güçleri hakkında bilgi edinmek için söylem ve iletişime gereksinim duyarlar (vanDijk, 2009, s. 198). Bir söylem olan haberde, egemen söylemler doğallaşıp ve egemen ideoloji yeniden kurulmaktadır (İnal, 1996, s. 100). Haber metninde anlam üretimi, olayların, olguların ikili karşıtlıklarla biz-onlar, yerli-yabanc1, elitist-popülist şeklinde sunulmasıyla gerçekleştirilmektedir. Haber söyleminde geleneksel değer yargılarının egemen olduğu düşünüldüğünden, iyi-kötü kavramı egemen değer yargılarının çerçevesini aşamamaktadır. Dış politika haberlerinde ise söylem, biz-onlar, dostlar-düşmanlar çerçevesinde kurulmaktadır (Aslan, 2004, s. $37)$.

\section{Bulgular}

12 Mart 2020 günü, araştırmanın örnekleminde yer alan gazetelerden yedi tanesinin yaklaşık birbirinin aynısı sayılabilecek ifadelerle manşetlerinde COVID-19'u haber ettikleri görülüyor. Söz konusu gazeteler ve manşetleri şöyledir: Takvim: "Panik Yok", Türkiye: "Endişeye Gerek Yok", Yeni Akit: "Panik Yok Tedbir Alındı", Cumburiyet: "En Tehlikeli Salgin: Panik", Yeni Şafak: "Tedbir Alındı Bu Panik Gereksiz", Sabab: "Kirli Bilgiye Kanmayın Her Şey Kontrol Altında", Milliyet: "Sakin Olun". Bu gazetelerin manşetlerinde öne çıkan sözcük "panik"tir. Hepsi de panik yapmanın gereksizliğine ve dolayısıyla sakin olmanın önem ve gereğine vurguda bulunmuştur. Siyasal iktidara karşı farklı ideolojik konumlara sahip bu gazetelerin benzer manşetleri tercih etmiş olmaları dikkat çekicidir. Toplumsal sorumluluk ideolojik konumlanıştan daha baskın çıkmış gibi görünmektedir. Söz konusu yedi gazetenin bu benzer manşetlerine karşılık örneklemi teşkil eden diğer sekiz gazeteden Yeni Asır ve Yeni Birlik'te COVID-19 salgınının manşetlik bir gündemde yer almadığı görülüyor. COVID-19 salgını bu iki gazetenin manşetinde yer bulmamıstır. Diğer altı gazetenin ise daha nötr sayılabilecek manşetlerle konuyu manşetlerine taşıdıkları görülmektedir. Bu gazetelerin manşetleri şöyledir: Karar: "Seferberlik", Sözcü: "Koranavirüse Karşı Ne Yemeli Ne İçmeli, Nasıl Korunmalı?”, Akşam: "Avrupa'dan Geldi Erken Başvurdu”, Hürriyet. "Önümüzdeki 2 Ay Kritik", Posta: "Fırsatçıya Geçit Yok", Korkusuæ: "Virüs Seferberliği’” manşetlerine yer vermiştir. Bundan da anlaşıldığı üzere kitle iletişim araçları tarafindan sunulan haberlerin her birisi dolayımlanmıs olarak hedef kitleye sunulmaktır. Zira kitle iletişim aracının yapısal ve işlevsel içeriği sadece bilgiden oluşmamakta, mevcut bilgi dolayımlanarak hedef kitleye hitap eden enformasyona dönüştürülmektedir. Bu ise COVID-19 örneğinde olduğu üzere, gündemin hem tüm dünyada hem de ülke ölçeğinde kaçınılmaz şekilde bir konuya odaklandığı zamanda bile kitle iletişim araçları haber olması beklenen mevcut olay veya olguya rağmen farklı tutumlar sergileyebilmektedirler.

Gazetelerin aynı gün benzer söylemi dile getiren manşete sahip olmalarının bir diğer örneği 19 Mart günü gerçekleşmiştir. Benzer olmanın da ötesinde neredeyse aynı söylemi dile getiren manşetlerin ortak sözcüğü "ekonomik paket”tir. Zira siyasal iktidar, 18 Mart akşamı COVID-19 salgınının neden olduğu ekonomik daralmanın ve diğer mevcut veya muhtemel ekonomik problemlerin çözümüne katkı sağlamak, genel olarak toplumu, özel olarak da ekonomi sektörünü rahatlatmak adına bir dizi ekonomik tedbir aldığını duyurmuş ve "tedbir paketinin" detayları hakkında açıklamada bulunmuştur. Bunun üzerine 19 Mart gününe ait gazetelerin önemli bir kısmı, söz konusu ekonomik önlem ve destekleri konu edinen 
haberleri manşetlerinden kitlelerle paylaştıkları görülmektedir. Bu durumla ilgili gazeteler ve manşetleri şöyledir: Takvim: "100 Milyarlık Kalkan", Yeni Birlik: "Virüse Ekonomik Kalkan", Türkiye: "Virüs İçin 100 Milyar", Yeni Akit: "Virüse Karș1 100 Milyar Liralık Ekonomik Kalkan", Yeni Safak "Devlet Böyle Olmalı", Akşam: "100 Milyarlık İstikrar Kalkanı", Sabab: "Güçlenerek Atlatacağız", Hürriyet: "100 Milyarlık Paket", Posta: "Ekonomik Kalkan". Manşetlerde ön plana çıkarılan sözcük "kalkan"dır. "Kalkan", korunmayı, tehlikeden zarar görmeyi engelleyen şeyi çağrıştıran bir sözcüktür. Dolayısıyla söz konusu manşetler ekonomik tedbirleri gerekli bulan ve bu açıdan iktidarın uygulamasını olumlu bulan bir söyleme sahiptirler. Hatta uygulamaya konan ekonomik tedbir ve teşviklerin olumlu bulunmasının ötesinde, siyasal iktidarın bu uygulama üzerinden pek de dolaylı olmayan bir şekilde de onaylanması söz konusudur. Bu aşamada hiç değilse ideolojik farklılıklar devre dışı kalmış gibi görünmektedir. Manşetler içerisinde en ilginç olanı Yeni Şafak'a aittir; gazete "Devlet Böyle Olmalı" manşetiyle çıkmıştır. Bu manşetteki söylem, iktidarı olumlamanın ötesinde öven ve yücelten bir anlayıșı hedeflemekte; hatta iktidarı örnek olarak takdim etmektedir. Gazetedeki manşet üstün haberin başlığı ise manşeti destekler niteliktedir: "Trilyonlarca Dolar Ayrrldı". Halbuki bu haberin konusu ABD'nin ekonomik destek paketiyle ilgilidir. Fakat manşet ile birlikte düşünüldüğünde bu haber başlı̆̆ı, Türkiye'deki ekonomik destek paketini ve dolayısıyla iktidarı destekleyen bir tutumun söylemi olarak anlam kazanmaktadır. Bilindiği üzere haber söylemi en önemli enformasyon etrafında inşa edilir, diğerleri ise çıkarılır ya da geriye itilir. Bu arada bazı eklentiler de olur. Habere ayrılan yer ya da zaman, dilin vurgu sistemi, kullanılan cümlelerin yapısı, seçilen yüklemler, zarflara, sıfatlara ayrılan yerler, bunların hepsi birer ideolojik seçimdir (Özerkan, 2002, s. 67). Sabah gazetesi ise 19 Mart günü manşetinde söz konusu ekonomik paketi olumlu bulduğunu ifade eden bir tutuma sahip olmakla birlikte, birlik/beraberlik çağrısı da yapma ihtiyacı hissetmiştir. Gazetenin manşeti "Güçlenerek Atlatacağız" şeklindedir. Bu manşet umut veren, mevcut zorluk ve sıkıntıların ağırlığını hafifletmeyi hedefleyen bir tutumun gereğine uygundur. Alt haber başlı̆̆ ise bu umudu daha da pekiştirir bir niteliğe sahiptir: "Paniğe Gerek Yok, Çaremiz Var". Bu manşetler ile üst ve alt haber başlıklarından da anlaşıldığ1 üzere, bir haber, iletilmek istenilen olay ya da mesajın bire bir kopyası değildir. Haber, yayınlanacağ1 organizasyonun yayın kimliği ve haber yapıcının sosyo-kültürel altyapısı göz önünde bulundurularak gerçekliğin yeniden inşasıdır (Cengiz, Çağlar, 2003, s. 172).

Tablo 1.Gazetelerin 11-20 Mart 2020 Tariblerindeki COVID-19 ile Illgili Mansetleri ve Üst-Alt Başllklarn

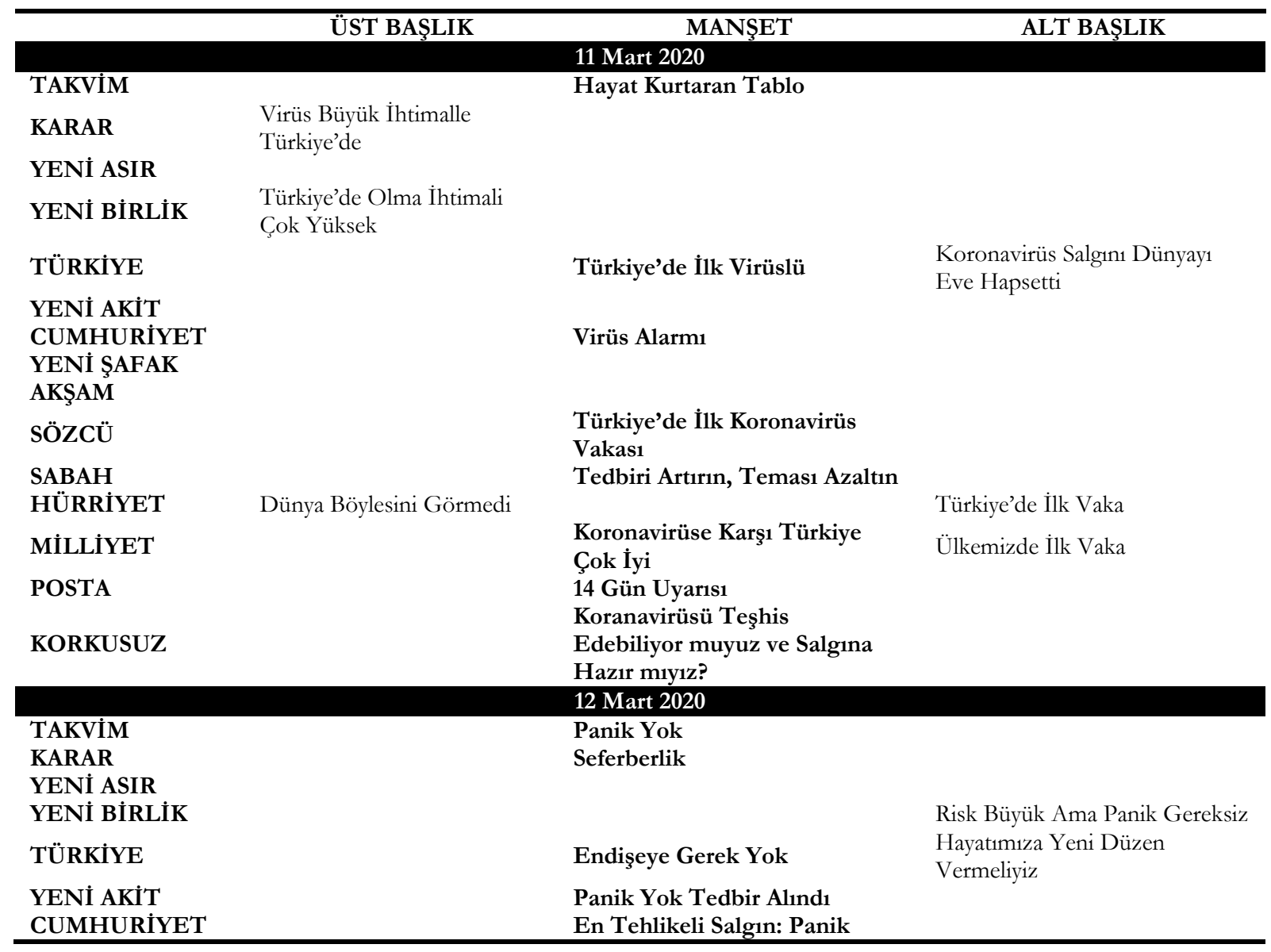


Tablo 1 -Devam

\begin{tabular}{|c|c|c|c|}
\hline & ÜST BAŞLIK & MANŞET & ALT BAŞLIK \\
\hline YENİ ŞAFAK & & $\begin{array}{l}\text { Tedbir Alındı Bu Panik } \\
\text { Gereksiz }\end{array}$ & \\
\hline AKŞAM & & $\begin{array}{l}\text { Avrupa'dan Geldi Erken } \\
\text { Başvurdu }\end{array}$ & Vurgun Virüsü Hortladı \\
\hline SÖZCÜ & Virüs Firsatçları & $\begin{array}{l}\text { Koronavirüse Karşı Ne Yemeli } \\
\text { Ne İçmeli, Nasıl Korunmalı? }\end{array}$ & Virüs Marketleri Boşalttı \\
\hline SABAH & & $\begin{array}{l}\text { Kirli Bilgiye Kanmayın Her Şey } \\
\text { Kontrol Altında }\end{array}$ & $\begin{array}{l}\text { Panik Yapmayalım Dikkatli } \\
\text { Olalım }\end{array}$ \\
\hline HÜRRİYET & Korona Anayasası & Önümüzdeki 2 Ay Kritik & $\begin{array}{l}\text { Alışverişi Abarttık / Virüse } \\
\text { Karşı Temizlik Şart }\end{array}$ \\
\hline MİLLIYET & & Sakin Olun & $\begin{array}{l}\text { İlk Şart Temizlik / Salgın Yok } \\
\text { Risk Ciddi }\end{array}$ \\
\hline POSTA & & Fursatçıya Geçit Yok & $\begin{array}{l}\text { Kolonya Kuyruğu / Termal } \\
\text { Kamera ile Virüs Önlemi }\end{array}$ \\
\hline KORKUSUZ & & Virüs Seferberliği & $\begin{array}{l}\text { Köşe Bucak Dezenfekte Edildi } \\
\text { / Üniversitelerden Koronavirüs } \\
\text { Karar1 }\end{array}$ \\
\hline & & 13 Mart 2020 & \\
\hline TAKVİM & & Temizeller Operasyonu & \\
\hline KARAR & Okullar Tatil & Dişimizi Sıkalım Atlatalım & \\
\hline YENİ ASIR & & & \\
\hline YENİ BİRLİK & $\begin{array}{l}\text { Okullar Tatil, Maçlar } \\
\text { Seyircisiz }\end{array}$ & $\begin{array}{l}\text { Tramp Avrupa'ya Seyahati } \\
\text { Yasakladi }\end{array}$ & Koca: 2 Ay Direnelim \\
\hline TÜRKIYYE & & Kendimizi Vuruyoruz & Okullar Bir Hafta Tatil \\
\hline YENİ AKİT & & $\begin{array}{l}\text { Virüs Kontrolde Kaosçular } \\
\text { Devrede }\end{array}$ & \\
\hline CUMHURIYYET & & Diren Türkiye & \\
\hline YENİ ŞAFAK & $\begin{array}{l}\text { Okullar Tatil, Maçlar } \\
\text { Seyircisiz }\end{array}$ & Türkiye Farkı & \\
\hline AKŞAM & Saçmalıklara İnanmayın & Şimdi Tatil Sonda E-Okul & Fiyat Artıran Hapse Girer \\
\hline SÖZCÜ & & & Koronavirüs Haziran'da Biter \\
\hline SABAH & $\begin{array}{l}\text { Koranavirüse Karşı } 14 \text { Altın } \\
\text { Kural }\end{array}$ & $\begin{array}{l}\text { Tük Okullar Tatil, Maçlar } \\
\text { Seyircisiz }\end{array}$ & $\begin{array}{l}\text { Ünlülerden Virüse Karş1 } \\
\text { Önlemler }\end{array}$ \\
\hline HÜRRİYET & & Fahrettin Bey'in 24 Saati & Kolonya 1 - Sirke 2 - Makarna 3 \\
\hline MİLLIYET & & $\begin{array}{l}\text { Kovid19 Algoritmas1 / Okullara } \\
\text { Korona Tatili }\end{array}$ & $\begin{array}{l}\text { İki Ay Direnelim /ABD } \\
\text { Avrupa'ya Kapıy Kapattı }\end{array}$ \\
\hline POSTA & & Okullar Tatil & 2 Ay Direnin \\
\hline KORKUSUZ & Okullara Virüs Tatili & $\begin{array}{l}\text { Koronavirüs Geçici Ama } \\
\text { İşsizlik Kalıcı }\end{array}$ & $\begin{array}{l}\text { Firsatçılar Virüsten Daha Hızlı } \\
\text { Yayılıyor }\end{array}$ \\
\hline & & 14 Mart 2020 & \\
\hline TAKVİM & $\begin{array}{l}\text { Avrupa'da } 9 \text { Ülkeye Uçuşlar } \\
\text { Durduruldu }\end{array}$ & Düşmanlık Virüsü & $\begin{array}{l}\text { Memleketimden Corona } \\
\text { Manzaraları }\end{array}$ \\
\hline KARAR & Vaka Sayısı 5’e Ç1ktı & Evde Eğitim Seçeneği Masada & \\
\hline YENİ ASIR & & & \\
\hline YENİ BİRLİK & & Virüsün Kaynağ1 ABD & Vaka Sayıs1 5’e Yükseldi \\
\hline TÜRKIYYE & & Bugün Yarın Maske Düşer & $\begin{array}{l}\text { Vaka Sayısı 5, Hepsi de Aile } \\
\text { Çevresinden } 7 \text { Evde Mesai Nasıl } \\
\text { Geçer? }\end{array}$ \\
\hline YENİ AKİT & & & \\
\hline CUMHURIYYT & & Türkiye'nin Sınavı & \\
\hline YENİ ŞAFAK & & Koronaya Karş1 Seferberlik & \\
\hline AKŞAM & $\begin{array}{l}9 \text { AB Ülkesine Kapılar } \\
\text { Kapatıldı }\end{array}$ & Turistik Tatil Risk & \\
\hline SÖZCÜ & & $\begin{array}{l}\text { Türkiye'de Virüslü Hasta } \\
\text { Sayısı 5'e Çıktı }\end{array}$ & \\
\hline SABAH & $\begin{array}{l}\text { Toplum Sağlığını Hiçe } \\
\text { Saydılar: Saygısızlar }\end{array}$ & Dersler TV'den ve İnternetten & Şüphesi Olan 184’ü Arasın \\
\hline HÜRRİYET & & Uzaktan Eğitim Böyle Olacak & $\begin{array}{l}\text { Vaka Sayıs1 5'e Çıktı / Araçtan } \\
\text { İnmeden Korana Testi }\end{array}$ \\
\hline MİLLIYET & & 5. Vaka & Uzaktan Eğitim Nasıl Olacak \\
\hline POSTA & & Seferberlik & $\begin{array}{l}\text { Avrupa'dan Korkutan Tablo / } \\
\text { Eldiven Kolonya }\end{array}$ \\
\hline KORKUSUZ & & Virüse İyi Gelen İlaç Bulundu & $\begin{array}{l}\text { Eve Dönüş / Koronavirüse } \\
\text { Karş1 Van Gölü Suyu }\end{array}$ \\
\hline
\end{tabular}


Tablo 1 -Devamı

\begin{tabular}{|c|c|c|c|}
\hline & ÜST BAŞLIK & MANŞET & ALT BAŞLIK \\
\hline & & \multicolumn{2}{|l|}{15 Mart 2020} \\
\hline TAKVİM & & Corona Aşısı Bulundu & $\begin{array}{l}\text { Virüs Moskovaya Sıçradı } \\
\text { /Temiztanbul }\end{array}$ \\
\hline KARAR & & En Sıkı Önlem En S1kı Takip & $\begin{array}{l}\text { İspanya'da Tamamen } \\
\text { Karantinada }\end{array}$ \\
\hline \multicolumn{4}{|l|}{ YENİ ASIR } \\
\hline YENİ BİRLİK & & Korona Gölgesinde Zirve & \\
\hline TÜRKİYE & & 21 Bin Kişi Gözetim Altında & Kaçak Yolcular Karantinada \\
\hline YENİ AKİT & & $\begin{array}{l}\text { Salgını Durdurduk Virüsü } \\
\text { Yeneceğiz }\end{array}$ & \\
\hline CUMHURİYET & & İkiyüzlü Dünya & \\
\hline YENİ ŞAFAK & & 90 Gün Engelledik & Kaçakçları İhbar Ediyorlar \\
\hline AKŞAM & $\begin{array}{l}\text { AVM'lere Virüs Ayarı / } \\
\text { Elinizi Türk Gibi Yıkayın }\end{array}$ & Lütfen Bize De Maske Birakın & \\
\hline SÖZCÜ & & Koronayak Olduk & $\begin{array}{l}\text { Türkiye'de Koronalı Hasta Sayıs1 } \\
6 \text { Oldu }\end{array}$ \\
\hline SABAH & & $\begin{array}{l}\text { Üniversitelerde Sanal Sınıf } \\
\text { Dönemi }\end{array}$ & $\begin{array}{l}\text { Korsan Uçaktaki } 57 \text { Yolcu } \\
\text { Karantinada }\end{array}$ \\
\hline HÜRRİYET & & Dünya Durdu & $\begin{array}{l}5300 \text { Umreci Bugün Dönüyor / } \\
\text { Vaka Sayısı Altıya Çıtı }\end{array}$ \\
\hline MİLLIYET & & Karantina Günlüğü & $\begin{array}{l}\text { İspanyol Gribi 1. Dünya } \\
\text { Savaşını Bitirmişti }\end{array}$ \\
\hline POSTA & $\begin{array}{l}\text { Koronavirüs Kayg1sı İle Baş } \\
\text { Etme Yolları }\end{array}$ & Korona Kalkanı & \\
\hline KORKUSUZ & $\begin{array}{l}\text { Emeklilere Koronavirüse } \\
\text { Karşı Destek Verilsin }\end{array}$ & $\begin{array}{l}\text { Çaya Çorbaya Limon, Taşa } \\
\text { Toprağa Dezenfektan }\end{array}$ & $\begin{array}{l}\text { Türkiye'de Virüslü Hasta Sayısı } \\
\text { 6'ya Çıktı / Dünyada Toplam } \\
\text { Ölü Sayısı } 6 \text { Bine Yaklaştı }\end{array}$ \\
\hline & & \multicolumn{2}{|l|}{16 Mart 2020} \\
\hline TAKVİM & $\begin{array}{l}\text { Emekliye } 602 \text { TL / Memura } \\
\text { Çifte Zam }\end{array}$ & Yurtta Karantina & $\begin{array}{l}\text { Evde Çocuğu Olana Corona } \\
\text { İzni }\end{array}$ \\
\hline KARAR & & Büyük Karantina & \\
\hline \multicolumn{4}{|l|}{$\begin{array}{l}\text { YENİ ASIR } \\
\text { YENİ BİRLİK }\end{array}$} \\
\hline TÜRKIYE & & Hani Sicakta Yaşamazdi? & $\begin{array}{l}\text { Virüs Ünlü Dinlemiyor / } \\
\text { Umreden Yurtlara }\end{array}$ \\
\hline YENİ AKİT & & Tedbirlerde Taviz Yok & \\
\hline CUMHURİYET & & Bilimden Kaçmayın & Tekstilde Virüs Yangını \\
\hline YENİ ŞAFAK & & Marketleri Asker Koruyacak & Yurtta Kalacaklar \\
\hline AKŞAM & Johnson'un Virüs Kumarı & Umrecilere Karantina & \\
\hline SÖZCய̈ & & Karantina Ziyareti & $\begin{array}{l}\text { İngiltere ve İsviçre'ye Uçuşlar } \\
\text { Durdurulsun }\end{array}$ \\
\hline SABAH & & Günlük Hayata Virüs Düzeni & $\begin{array}{l}\text { Umreden Dönenler Karantinaya } \\
\text { Alındı }\end{array}$ \\
\hline HÜRRİYET & & Temastan Kaçın Mesafeyi Koru & $\begin{array}{l}\text { Umre Dönüşü Dev Karantina / } \\
\text { Koronayı Yakında Alt Ederiz }\end{array}$ \\
\hline MİLLIYYET & & Temassız İhracat & $\begin{array}{l}\text { Birlikte Yeneriz / Umreden } \\
\text { Dönene Karantina }\end{array}$ \\
\hline POSTA & & Şakası Yok & \\
\hline KORKUSUZ & $\begin{array}{l}\text { Grip Aşısı Olanlar Avantajlı } \\
\text { Mı? }\end{array}$ & 10 Bin 330 Kişi Karantinada & $\begin{array}{l}\text { Türkiye'de Virüslü Hasta Sayısı } \\
\text { 18'e Çıktı }\end{array}$ \\
\hline & & 17 Mart 2020 & \\
\hline TAKVİM & Coronaya Doğal Darbe & Büyük Önlem & $\begin{array}{l}\text { Tüm Dünyada Meydanlar } \\
\text { Bomboş / İngiltere'de Gizli } \\
\text { Rapor }\end{array}$ \\
\hline KARAR & & Kritik 10 Gün & $\begin{array}{l}\text { Cemaatle Namaza Ara / } \\
\text { Kahvehanelere Kilit }\end{array}$ \\
\hline \multicolumn{4}{|l|}{ YENİ ASIR } \\
\hline YENİ BİRLİK & Ekonomide Korona Hamlesi & & $\begin{array}{l}\text { Mekanlar Kapandı / Cemaatle } \\
\text { Namaza Virüs Arası }\end{array}$ \\
\hline TÜRKIYYE & & Yalan Salgını & $\begin{array}{l}\text { Camide Cemaatle Namaza Ara / } \\
\text { Hepsi De Yurtdışı Temaslı }\end{array}$ \\
\hline YENİ AKİT & & Asıl Virüs Bunlar & Camide Cemaatle Namaza Ara \\
\hline
\end{tabular}


Tablo 1 -Devam

\begin{tabular}{|c|c|c|c|}
\hline & ÜST BAŞLIK & MANŞET & ALT BAŞLIK \\
\hline CUMHURİYET & & Şeffaflık Yener & Eğitimde Kayıp Y1l \\
\hline YENİ ŞAFAK & $\begin{array}{l}\text { Camilerde Cemaatle Namaza } \\
\text { Ara }\end{array}$ & Türkiye'ye Gelmek İstiyorlar & Sokağa S1k1 Önlem \\
\hline AKŞAM & $\begin{array}{l}\text { En İyi İlaç Vücut Direnci / } \\
\text { Evden Çıkma }\end{array}$ & Karantina Firarisine Ağır Ceza & $\begin{array}{l}\text { Test Kitini Tüm İllere } \\
\text { Göndereceğiz }\end{array}$ \\
\hline SÖZCÜ & $\begin{array}{l}\text { Virüs Ekonominin Ateşini } \\
\text { Yükseltti }\end{array}$ & Olağanüstü Önlemler & $\begin{array}{l}\text { Tramp Aşı Bulan Alman } \\
\text { Firmasına } 1 \text { Milyar \$ Teklif Etti } \\
\text { / } 16 \text { İldeki Öğrenci Yurtları } \\
\text { Karantina Merkezi Yapıllyor }\end{array}$ \\
\hline SABAH & & $\begin{array}{l}\text { Devlete Güveniyorum, } \\
\text { Kurallara Uyuyorum }\end{array}$ & $\begin{array}{l}\text { Kapalı MekanlaraKoranavirüs } \\
\text { Kilidi / Cemaatle Namaza Ara }\end{array}$ \\
\hline HÜRRİYET & $\begin{array}{l}\text { Bunlar1 Yapın/Bunlar1 } \\
\text { Yapmayın }\end{array}$ & Hepsi Kapandı & $\begin{array}{l}\text { Toplu Namaza Virüs Molası / } \\
\text { Sahillere Kaçtlar }\end{array}$ \\
\hline MİLLIYYT & & Tedbirler Peş Peşe & $\begin{array}{l}81 \text { İle Test Kiti / Dünyada } \\
\text { Kovid /19 Günlüğü (Can Kayb1 } \\
7139 \text { ) }\end{array}$ \\
\hline POSTA & & Artık Sira Bizde & $\begin{array}{l}\text { Bütün Ülkeye Test Kiti / Bu } \\
\text { Virüslerden Nasıl Kurtulacağı? }\end{array}$ \\
\hline KORKUSUZ & & Ekonomiye Virüs Darbesi & Türkiye Karantinada \\
\hline & & 18 Mart 2020 & \\
\hline TAKVİM & Emekliye Evde Ödeme & Corona Belden Aşağ1 Vuruyor & $\begin{array}{l}\text { Tatil Uzayabilir / Bodruma } \\
\text { Gelmeyin }\end{array}$ \\
\hline KARAR & & $\begin{array}{l}\text { Bu Kâbusu Atlatmanın Yolu } \\
\text { Var }\end{array}$ & \\
\hline YENİ ASIR & & & \\
\hline YENİ BİRLİK & & Zirvenin Gündemi Virüs & İTÜ’de Test Kiti Başarıldı \\
\hline TÜRKIYYE & & Korona 80 Yildır Var & $\begin{array}{l}\text { Virüsten İlk Kayıp / Virüslere } \\
\text { Karşı Havayı Temizleyin }\end{array}$ \\
\hline YENİ AKİT & & Evlerimizi Mescide Çevirelim & \\
\hline CUMHURİYET & & Onlar Böyle Başardı & \\
\hline YENİ ŞAFAK & $\begin{array}{l}\text { Bu Zor Süreçte Birlikte } \\
\text { Çalışalım }\end{array}$ & Sınavı Geçtik & $\begin{array}{l}\text { Güven Tam / Kovid-19'dan İlk } \\
\text { Kaybımız }\end{array}$ \\
\hline AKŞAM & $\begin{array}{l}\text { Kapatma Kararına Uymayan } \\
\text { İsyerine A ğır Yaptırım }\end{array}$ & $\begin{array}{l}\text { Korona Mutabakatı / Virüs } \\
\text { Yayana Suçüstü } \\
\end{array}$ & \\
\hline SÖZCÜ & & $\begin{array}{l}\text { Türkiye Kilitlendi Esnaf } \mathrm{Ne} \\
\text { Yapacak? }\end{array}$ & $\begin{array}{l}\text { Karantinayı İhlal Edene } 1 \text { Yil } \\
\text { Hapis }\end{array}$ \\
\hline SABAH & & $\begin{array}{l}12 \text { Milyon Emekliye Virüse } \\
\text { Karş1 Koruma }\end{array}$ & $\begin{array}{l}\text { Avrupa'da Milyonlar Evlerine } \\
\text { Kapand.. }\end{array}$ \\
\hline HÜRRİYET & & İzolasyonu Beceriyoruz & $\begin{array}{l}\text { Türkiye'de Koronavirüsten İlk } \\
\text { Ölüm } \\
\text { Virüs Önleminde En Kritik } \\
\text { Zirve }\end{array}$ \\
\hline MİLLIYET & & Evde Kal Türkiye & $\begin{array}{l}\text { Türkiye'de Gündem Virüs } \\
\text { /Kovid 19'dan İlk Can Kayb1 }\end{array}$ \\
\hline POSTA & & Birlikte Yeneceğiz & \\
\hline KORKUSUZ & & $\begin{array}{l}\text { Alınan Önlemlere Uyulursa } 5 \\
\text { Bin, Uyulmazsa } 30 \text { Bin Kişi } \\
\text { Virüsten Etkilenir }\end{array}$ & $\begin{array}{l}\text { Virüse İlk Kurban / Meydanlar } \\
\text { Bomboş }\end{array}$ \\
\hline & & 19 Mart 2020 & \\
\hline TAKVİM & $\begin{array}{l}\text { Emekliye Evde Maaş / } \\
\text { Koronavirüs Elimizden } \\
\text { Kaçamaz }\end{array}$ & 100 Milyarlık Kalkan & \\
\hline KARAR & & $\begin{array}{l}\text { Singapur Olmadık İtalya } \\
\text { Olmayalım }\end{array}$ & Kovid Paketi \\
\hline \multicolumn{4}{|l|}{ YENİ ASIR } \\
\hline YENİ BİRLİK & & Virüse Ekonomik Kalkan & \\
\hline TÜRKIYYE & & Virüs İçin 100 Milyar & $\begin{array}{l}\text { Vatandaş Öyküsünü Gizliyor / } \\
\text { Koronavirüste İkinci Kaybımız }\end{array}$ \\
\hline YENİ AKİT & $\begin{array}{l}\text { Yaşlılarını Ölüme Terk } \\
\text { Ettiler }\end{array}$ & $\begin{array}{l}\text { Virüse Karş1 } 100 \text { Milyar Liralık } \\
\text { Ekonomik Kalkan }\end{array}$ & Avrupa Gıdayı Karneye Bağladı \\
\hline CUMHURIYYT & Salgının Göbeğinden & Testten Kaldık & Kaynaksız Paket \\
\hline
\end{tabular}


Tablo 1 -Devamı

\begin{tabular}{|c|c|c|c|}
\hline & ÜST BAŞLIK & MANŞET & ALT BAŞLIK \\
\hline YENİ ŞAFAK & Trilyonlarca Dolar Ayrildı & Devlet Böyle Olmalı & \\
\hline AKŞAM & $\begin{array}{l}\text { Mucize İlaç Japonya'dan / } \\
\text { Koronavirüse Karşı Direnç } \\
\text { Bu Tabakta }\end{array}$ & 100 Milyarlık İstikrar Kalkanı & $\begin{array}{l}\text { Türkiye'ye Daha Çok Yardıma } \\
\text { Hazırız / Koronadan İkinci } \\
\text { Ölüm }\end{array}$ \\
\hline SÖZCÜ & İşte Beklenen Korona Paketi & $\begin{array}{l}\text { Ne Kadar Test O Kadar } \\
\text { Koruma }\end{array}$ & Kapalı Çarşı \\
\hline SABAH & & Güçlenerek Atlatacağız & $\begin{array}{l}\text { Dünyaya Umut Olan İki İlaç / } \\
\text { Paniğe Gerek Yok Çaremiz Var }\end{array}$ \\
\hline HÜRRİYET & & 100 Milyarlık Paket & $\begin{array}{l}\text { Virüse Karş1 Sabun Mu Kolonya } \\
\text { Mi? / İkinci Ölüm } 97 \text { Yeni } \\
\text { Hasta }\end{array}$ \\
\hline MİLLIYYET & & Evinizden Çıkmayın & $\begin{array}{l}\text { Öksüren Pazara Gitmesin / } \\
\text { Kovid-19'dan İkinci Can Kayb1 }\end{array}$ \\
\hline POSTA & & Ekonomik Kalkan & \\
\hline KORKUSUZ & & $\begin{array}{l}\text { En Düşük Emekli Maaşı } 1500 \\
\text { Lira Oldu }\end{array}$ & Sahtekâr Fırsatçılar / Kapalıçarşı \\
\hline & & 20 Mart 2020 & \\
\hline TAKVİM & 2 Milyon Kişiye 1000 'er Lira & $\begin{array}{l}\text { Virüst Akıl (Bize Bir Şey } \\
\text { Olmaz) }\end{array}$ & 2. Kurban Yalman \\
\hline KARAR & & Test TestTest & \\
\hline YENİ ASIR & & & \\
\hline YENİ BİRLİK & & Erdoğan Uyarmış & \\
\hline TÜRKİYE & & Mahkumlara Virüs Tahliyesi & $\begin{array}{l}\text { Asya Atlatıyor Avrupa } \\
\text { Çrpıniyor / Dersler } 20 \text { Dakika }\end{array}$ \\
\hline YENİ AKİT & İstikrar Paketine Tam Destek & İşte Türkiye Farkı & \\
\hline CUMHURİYET & & Virüs Affı & \\
\hline YENİ ŞAFAK & $\begin{array}{l}\text { Türkiye Bu Süreçten Güçlü } \\
\text { Çıkacak / Günde } 15 \text { Bin } \\
\text { Korona Testi }\end{array}$ & Avrupa Yoğun Bakımda & Restoranlarda 1 Metre Şartı \\
\hline AKŞAM & Her Gün 15 Bin Test & Koronaya Evde Takip & \\
\hline SÖZCÜ & & $\begin{array}{l}\text { ABD Para Veriyor, İktidar Vaat } \\
\text { Veriyor }\end{array}$ & $\begin{array}{l}\text { Yalman Paşa Spor Salonunda } \\
\text { Virüs Kapı Öldü }\end{array}$ \\
\hline SABAH & & $\begin{array}{l}\text { Yerli Tanı Kitiyle Günde } 15 \text { Bin } \\
\text { Test }\end{array}$ & $\begin{array}{l}\text { 15'liler Virüse Karşı } \\
\text { Seferberlikte / Her Kesimi } \\
\text { Kucaklayan Bir Paket Hazırladık }\end{array}$ \\
\hline HÜRRİYET & Liglere Korona Aras 1 & Minnettariz & $\begin{array}{l}\text { Yalman Paşa da Virüsten Ölmüşs } \\
\text { / Paketli Ürünü Evde Yıkayın }\end{array}$ \\
\hline MİLLİYET & & Sınavlara Soru Ayarı & $\begin{array}{l}\text { Türkiye Sağlıkçıları Alkışladı } \\
\text { /İtalya’da Kayıp Çin’i Geçti. }\end{array}$ \\
\hline POSTA & & Doktorumuzdan Müjde Var & \\
\hline KORKUSUZ & & Bu Nasıl İş? & Yalman Paşa Virüsten Ölmüş \\
\hline
\end{tabular}

19 Mart günü örneklemdeki dokuz gazetenin, uygulamaya konan ekonomik destek paketini olumlu bulduklarını ifade eden benzer manşetlerle yayınlanmış olmasına karşılık, YeniAsır, ekonomik destek paketini de COVID-19'u da manşetine taşımamıştır. Karar "Singapur Olmadık, İtalya Olmayalım" manşetiyle iktidarı ve toplumu sorumlu olmaya davet eden bir manşeti tercih etmiştir. Cumburiyet ise "Testten Kaldık" manşeti üzerinden genelde siyasal iktidarı, özelde ise Sağlık Bakanlığı'nı eleştiren bir söylemi haber konusu edinirken, "Kaynaksız Paket" alt başlıklı haberiyle ekonomik destek paketine eleştiri yöneltmiştir. Milliyet gazetesinin manşeti "Evinizden Çıkmayın" şeklinde olup, kitlelere yönelik uyarıda bulunmayı tercih etmiş ve ekonomik destek paketini gündemine almamışır. Manşet altındaki haberin başlığ1 ise, manşet uyumlu olup, “Öksüren Pazara Gitmesin” şeklindedir. Gazeteler arasındaki bu ayrışmanın temelinde söylem farklılığ1 vardır. Bir farklılıklar ağı olarak söylemler, ideolojiyi kuşatır ve yoruma teslim olur. Çünkü söylemler ideolojileri kuşatır; ancak onların yoruma ihtiyaçları vardır. Yorumun varoluş nedeni söylemdir ve yorumsuz söylem bir hiçtir (Sözen, 1999, s. 12). Bu bağlamda gazetelerin ekonomik destek paketi üzerinden ideolojik konumlanışlarına bağlı olarak söylemlerini konuşturdukları ve yorumlarıyla da duruşlarını ortaya koydukları gözlenmektedir. Günün gazete manşetlerine yansıyan asıl gündemi ekonomik destek paketi olmasına ve bunun üzerinden iktidarın uygulamasına yönelik olumlu bir tutum takınılmasına karşıllk, Korkusuz. kısmen Cumburiyet gazetesinin söylemiyle örtüşen bir yaklaşımla, iktidarı sosyo-ekonomik politikalarından dolayı eleştiren bir manșeti tercih etmiștir. Manșet "En Düşük Emekli Maaşı 1500 Lira Oldu" şeklindedir. Bilindiği üzere bir haber toplumsal bir olay üzerine yapılabilecek ve kabul edilebilecek muhtemel yorumlar arasından bir seçme yapmak zorundadır. Bu durum 
bazı zamanlar kabul edilebilir olmanın ötesine taşınarak, ahlaki açıdan kabul edilemeyecek bir yanlılığa yönelebilmektedir (Belsey, Chadwick, 1998, s. 142). Zira dolayımlama haberde iki kez gerçekleştirilir. Birinci aşamada dolayımlama; haberin içinde barındırdığı bilgi enformasyona, olay öyküye, kaynak aktöre, ilgi eğlenceye çevrilerek yapılır. İkinci aşamadaki dolayımlama ise dağıtımı yapacak medya organizasyonunun yapısına, teknoloji kullanımına, yayın kimliği ve yayın politikasına göre gerçekleştirilir (Rigel, 2000, s. 188). Bu bakımdan gazete manşetleri örneklerin bol bulunabileceği yerler olarak anlam kazanmaktadir.

Kitle iletişim araçlarının farklı mecralarında inşa olan haberler, yalnızca nesnel gerçekliğe ilişkin yargılarla sınırlı kalmamaktadır. Ekonomik, siyasal, kültürel farklılıklara bağlı olarak insanların habere konu olan olayları oldukça farklı tarzlarda yorumladıkları, tasarımladıkları, değerlendirdikleri ve böylece farklı kanaatler, tutumlar ve ideolojiler oluşturdukları aşikârdır (Küçük, 1999, s. 370). Bu açıdan COVID-19 salgınının gazetelerde haber edilme tarzı önemli örneklerle doludur. Olayın özel öneminden veya etki kapsamının büyüklügünden dolayı bazı durumlarda olayın haber edilişindeki söylem farklı gazetelerde benzerlik gösteriyor olsa bile, çoğu zaman söylem farklılaşması haberin önceliklerini, sunuş tarzını ve sunuş ifadelerini radikal şekilde değişikliğe uğratabilmektedir. Bu açıdan araştırmanın örneklemini teşkil eden gazetelerin büyük çoğunluğunun benzer söylem ve ifadeler taşıyan manşetlerle yayımlandığ1 12 ve 19 Mart günleri dışındaki araştırmanın yürütüldüğü diğer günlerdeki manşetleri ve üst-alt haberleri dikkate alındığında, önemli örnekler tespit edilebilmektedir. İktidar yanlısı veya karşıtı tutamlarıyla genel olarak iktidarın, özellikle de Sağlık Bakanlığı ve İçişleri Bakanlığı başta olmak üzere konuyla ilgili bakanlıkların COVID-19'a yönelik tedbir ve uygulamalarını olumlu veya olumsuz bulmanın da ötesinde övücü veya yerici ifadelerle yücelten veya aşağllayan söylemleri manşetlerinde dile getiren gazeteler ve manşetleri dikkat çekicidir. Bunlardan Milliyet gazetesinin 11 Mart gününe ait manşeti ilginçtir. 11 Mart günü COVID-19 vakasının Türkiye'de ilk göründüğü günün ertesini oluşturmaktadır ve ulusal gazetelerin tamamına yakını manşetlerinde COVID-19'a yer vermişler, büyük çoğunluğu da bunu bilgilendirme bağlamında yapmıştır. Örneğin Türkiye gazetesinin manşeti “Türkiye'de İlk Virüslü”, Sözcü gazetesinin manşeti ise "Türkiye'de İlk Koranavirüs Vakası" şeklindedir. Fakat Milliyet gazetesinin o günkü manşeti "Koranavirüse Karşı Türkiye Çok İyi" şeklinde belirlemiştir. Halbuki daha ilk vaka görülmüş ve sürecin neler getireceği belli olmamıştır. Bu bağlamda aynı güne ait Korkusuz gazetesinin manşeti ise, her ne kadar uyarı/hatırlatma niteliğine sahip gibi görünüyorsa bile, esasen eleştirel bir sözlemi barındırmaktadır: "Koranavirüsü Teşhis Edebiliyor muyuz ve Salgina Hazır miyı?”

Gazetelerin siyasal iktidar karşısında ideolojik konumlanışları ve bu konumlanışın gerektirdiği söylem farklılıkları takip eden günlerdeki manşetlerde ve diğer bazı haber başlıklarında olanca açıklığıla kendisini ortaya koymuştur. 13 Mart tarihli Yeni Şafak gazetesinin manşeti “Türkiye Farkı" şeklinde olup, sürecin daha başlangıcından itibaren Türkiye ile Avrupa ülkeleri arasında bir karşılaştırma yaparak, Türkiye'nin salgınla mücadelesinin, hastalara yönelik tutum ve davranışların, tedaviye yönelik uygulamaların diğer ülkelerinkine oranla son derece olumlu, başarlı olduğunu dile getirme ihtiyacı hissetmiştir. Tabi ki bu karşılaştırma sadece söylemde yapılmış, somut ve detaylı nesnel verilere dayandırılmamıştır. Bu tutumun karşı kutbunda yer alan Korkusuz gazetesi ise gündem COVID-19 salgını ile ilgili olmasına rağmen iktidar karşıtı rutin tutumunu sürdürme ihtiyacı hissetmiş ve manşetini "Koranavirüs Geçici Ama İşsizlik Kalıcı" şeklinde belirlemiştir.

Yeni Akit gazetesi 15 Mart günü "Salgını Durdurduk Virüsü Yeneceğiz" manşetiyle yayınlanmıştır. Halbuki ilk vakanın görülmesinin üzerinden 4 gün geçmiş bulunmaktadır ve karantina süresi 14 gündür. Dolayısıyla salgının durdurulmuş olup-olmadığının bugünde belirlenmesi mümkün değildir. Yeni Şafak. gazetesinin manşeti ise geçmişe atıfla iktidarın uygulamalarını başarılı ilan etme amacına sahip bir söylemi dile getirmektedir: "90 Gün Engelledik". Bu "tespitin” de nesnel bir dayanağ1 söz konusu değildir. İlk vaka öncesi virüse yönelik kamu ve özel kuruluşlar çok farklı tedbirler almışlar, bireyler de bu kapsamda rutin yaşamlarında bazı değişikliklere gitmişlerdi, ancak tüm bunların COVID-19 virüsünün Türkiye'de görünmesini 90 gün veya daha az-daha çok süre engellediğiyle ilgili bir veri bulunmamaktadır. Aynı günün Korkusuz gazetesinin manşeti da ilginç bir niteliğe sahiptir. Korkusuz, alınan önlemleri olumlu buluyor gibi görünen fakat sürecin işleyişini komik bulduğunu hissettiren bir manşeti tercih etmiştir: "Çaya Çorbaya Limon, Taşa Toprağa Dezenfektan". Bu manşet haber metninin oluşturulması ile ilgili tespitlerin somut örneği olarak anlam kazanmaktadır. Mora'nın tespitleriyle ifade etmek gerekirse, bir haber metni oluşturulurken işleyen süreç şöyle gerçekleşir: "Haber söylemi en önemli enformasyon etrafında inşa edilmekte, diğerleri çıkarılmakta ya da geriye itilmekte ve bu arada bazı eklentiler de yapılmaktadır. Habere 
ayrılan yer ya da zaman dilimi, dilin vurgu sistemi, kullanılan cümlelerin yapısı, seçilen yüklemler, zarflara, sifatlara ayrılan yerler, bunların hepsi birer ideolojik seçim olarak değerlendirilmektedir. Haber metinlerinde, sıfatların kullanılmaması ya da en azından dengeli olarak dağıtılmaması, farklı görüşlere yer verilirken dengenin gözetilmemesi ve metin içindeki çeşitli iddialara simetrik olarak yer verilmemesi haberin taraflı olduğu konusunda bize bilgi vermektedir. Medya içeriği, toplumdaki iktidar ilişkilerinin kabataslak bir haritasını oluşturmaktadır" (Mora, 2004).

17 Mart tarihli Sabah gazetesinin manşeti "Devlete Güveniyorum, Kurallara Uyuyorum” şeklindedir. Bu manşet COVID-19 kapsamında yürütülen önlemlerin toplumsal bir probleme yol açmasını ve uygulamaların eleştiri konusu yapılmasını önleme arzusunun izlerini taşımaktadır. Bu açıdan manşet altı haber başlıkları dikkat çekicidir "Kapalı Mekânlara Koranavirüs Kilidi”, "Cemaatle Namaza Ara". Bu iki alt haberin konucu kitlelerin rutinlerinde gerçekleşen değişimle ilgilidir. Gazete ise bu değişimin yol açacağı gerilimi manşeti üzerinden azaltma amacına sahiptir. Öte yanda Türkiye ve Yeni Akit gazetelerinin COVID19 kapsamında yer alan mevcut sorunların sebebini iktidarın dışında aramanın çabası ile geleneksel "iç ve dış düşmanlar" söylemini çağrıştıran manşetleri tercih ettikleri görülmektedir. Bu bağlamda Posta gazetesinin 18 Mart tarihli manşeti oldukça önemlidir "Birlikte Yeneceğiz". Bu manşet söz konusu çağrışımın gerektirdiği tutumun ne olmasını ifade eder gibidir. 18 Mart gününün gazetelerinden Sabah ve Hürriyet gazeteleri ise umut yükselten bir söylemin şekillendirdiği manş̧etlere sahiptirler: Sabab: "12 Milyon Emekliye Virüse Karş1 Koruma”, Hürriyet: "İzolasyonu Beceriyoruz". Sabah ve Hürriyet gazetelerinin bu tutumlarını takip eden günlerde de sürdürdükleri görülüyor. Hürriyet gazetesinin 20 Mart gününe ait manşeti "Minnettarı", Sabah gazetesinin manşeti ise "Yerli Tanı Kitiyle Günde 15 Bin Test" şeklindedir. $\mathrm{Bu}$ arada Cumburiyet gazetesi muhalif tutumunun gereğine uygun olarak "İkiyüzlü Dünya" (15 Mart), "Bilimden Kaçmayın" (16 Mart), "Şeffaflık Yener" (17 Mart), "Onlar Böyle Başardı" (18 Mart), "Testten Kaldık" (19 Mart), "Virüs Affi" (20 Mart) manşetleri ile doğrudan veya dolaylı eleştirel tutumunu sürdürmeyi tercih etmiştir. Benzer tutum Söz̧ü gazetesinin manşetlerine de yansımıştır. Söz̧cü gazetesi ilk vakanın görülmesini takip eden ilk günlerdeki manşetlerinde daha nötr bir söylemi tercih ederken, sonraki günlerde ağırlıklı olarak eleştirel tutumunu sürdürmeyi tercih etmiştir: "Koranayak Olduk" (15 Mart), "Olağanüstü Önlemler" (17 Mart), "Türkiye Kilitlendi, Esnaf Ne yapacak?” (18 Mart), "ABD Para Veriyor, İktidar Vaat Ediyor" (20 Mart). Tüm bunlar iletişim literatüründe özel önem ifade eden "eşikbekçiliğı" (gatekeeping) olgusunu hatırlatmaktadır. Neyin haber değeri taşıdığı ve bu seçimi kimlerin yaptığı üzerine tartışmalar, eşikbekçiliği olgusunu gündeme getirmektedir. İlk kez 1947'de sosyo-psikolog Kurt Lewin tarafindan kullanılan eşikbekçiliği, "Bir ortam için yararsız görülen veya istenmeyen şeylerin ortam dışında bırakılması, girişlerinin engellenmesi" (Mutlu, 1995, s. 122) şeklinde tanımlanmaktadır. Eşikbekçiliği, haber üretim süreci içinde bilgi, yorum ve görsel-işitsel malzemenin, aracı yayın kimliği ve politikasına uygun olarak seçilmesi işlemidir; dolayısıyla muhabirden servis şefi, haber müdürü, yazı işleri müdürü ve genel yayın yönetmenine kadar herkes " $M r$. Gate" rolünü üstlenebilir. Mesajın hedefi olan haber alıcıları da bir ölçüde eşikbekçisidir; çünkü kendi ihtiyaçlarına göre göre malzemeyi seçer ve yorumlarlar (White, 1950, s. 390).

\section{Sonuç}

İktidar olgusu, güç ve rıza olgularını bünyesinde barındırır. İktidarın ve uygulamalarının (gücünün) meşruiyetinin temelinde "rıza" vardır. Bu nedenle günümüz siyasal rejimlerinde rızanın kazanılması doğrultusunda toplumun ikna edilmesine yönelik faaliyetlere özel bir önem verilmektedir. Çünkü "rıza"nın gerçekleşebilmesi, kitlelerin "ikna" olmalarıyla doğrudan ilgilidir. Bu sürecin işlemesinde ve sonuçta rızanın inşa edilmesinde günümüzün en önemli aracı medya, bizim bu makalede tercih ettiğimiz ismiyle kitle iletişim araçlarıdır. Bu sebeple iktidarlar, rızaya uzanan süreçte en çok kitle iletişim araçlarına başvurmakta; iktidarı onaylayan toplumsal zihniyetin yaratılması ve buna bağlı olarak rızanın kazanılmasında, bahsi geçen araçların sunduğu tüm olanaklardan faydalanılmaktadır. Fakat tüm bunlar yapıllırken inşa edilmeye çalışılan "rıza"nın yönü ve amacı değişmektedir. Bazı kitle iletişim araçları siyasal iktidarın uygulamalarına rıza inşa etmeye yönelik çaba yürütürken, diğer bazıları ise siyasal iktidarın karşıtı konumlanışın referansı olan iradeye/güce rıza göstermeyi tesis etmenin çabasını yürütmektedir. Bu ayrışmanın temelinde ise ideolojik farklılaşma vardır. Zira ideoloji kitle iletişim araçlarına bir konumlanış sunmakta ve bu konumlanış üzerinden olay ve olguları anlama ve yorumlama imkânı sunmaktadır. Bilindiği üzere ideoloji, en genel anlamıyla, olay ve olgulara yanlı bakışın ismidir. Dolayısıyla tüm ideolojiler bünyelerinde bir yanlılık barındırmaktadır. Ancak, bir kesim için var olan ideolojiler, toplumun geri kalan kesimlerinin karşısında yer almaktadır. Varlığını böyle bir ikilem üzerine şekillendiren kavram, "biz" ve "diğerleri”" üzerinden bir 
düşünce sistemi oluşturmaktadır. Her bir ideolojik paradigma, yumak haline gelmiş siyasal bilgilerden kendi kavramsal yapısını inşa etmekte ve şemsiyesi altında bulunan kimselere yol haritası sunmaktadır.

Bu makalenin konusu COVID-19 salgını (pandemisi) ile ilgilidir. COVID-19 salgınına ilişkin Türkiye ölçeğinde alınan sağlık tedbirlerinin, ekonomik kısttlama ve teşviklerin, bireysel ve toplumsal yaşama getirilen sınırlamaların ulusal gazete manşetlerinde nasıl haber edildiği araştırmanın konusunu oluşturmuştur. Kuşku yok ki, haber edişte gazetelerin ideolojik konumlanışları belirleyici olmakta, ideolojik konum ise haber metinlerinde işlevsel olan söylemlere yansımaktadır. Tüm bunlar bağlamında olmak üzere Türkiye'de COVID-19 vakasının ilk görüldüğ̈̈ 10 Mart 2020 günü ve sonrasındaki 10 günlük süredeki 15 ulusal gazetenin manşetleri söylem analizi tekniği ile incelenmiştir. Araştırmanın temel bulgularına göre, gazeteler siyasal iktidarın COVID-19 salgını kapsamında gerçekleştirdiği uygulamalara ideolojik konumlanışlarının etkisini taşıyan bir söylemle işlenen haber metinleri üzerinden kitlelere hitap etmişler; kitleler ile aralarındaki ideolojik ilişkiyi sürdürmenin çabasını yürüttükleri tespit edilmiştir. Böylelikle iktidarın uygulamalarını destekleyen ve hatta övgülerle modelleştiren gazete manşetlerinin yanı sıra uygulamaları eleştiren ve hatta aşağılayan manşetler de tespit edilmiştir. Bu da şaşırtıcı değildir. Çünkü genelde kitle iletişim araçlarının özelde ise gazetelerin yaygın olarak bilinen amacını "haberdar etmek" oluşturmaktadır. Haberdar etmenin nesnesi haberdir. Haber ise bir çerçevelemedir. Bu çerçeveleme olayın habere dönüştürülmesi sürecini içermektedir. Seçme ve eleme süreci olarak nitelenebilecek olan bu süreç ise eşikbekçilerinin inisiyatifi ile gerçekleşmektedir. Eşikbekçilerinin farklılaşmasını sağlayan şey ideolojik konumlanışlarındaki farklıııtır. Bu farklılık haberi çerçeveleme tarzlarını ve haber ile amaçladıkları şeyin farklılaşmasına yol açabilmektedir. Bahsi geçen yanlılık faaliyetleri; açıkça çarpıtma, bazı haberleri gereğinden fazla öne çıkarma, bazı olayları abartırken bazı olaylardan hiç bahsetmeme ya da bazı olayları hiç olmamışçasına gündeme taşımama şekillerinde yürütülmektedir. Toplumsal hayata ilişkin önemli olayların mevcut iktidar aleyhine olması durumunda, magazinleştirilerek içinin boşaltılması ya da iktidar kanadının lehine yorumlanabilecek olayların gereksiz abartılması medyada yanlılığın somutlaştığı haber sunma tekniklerinden birkaçıdır.

\section{Etik Beyan}

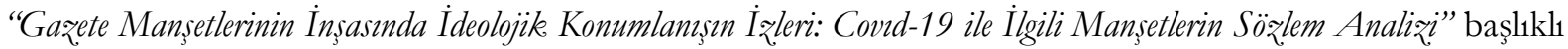
çalışmanın yazım sürecinde bilimsel, etik ve alıntı kurallarına uyulmuş; toplanan veriler üzerinde herhangi bir tahrifat yapılmamış ve bu çalışma herhangi başka bir akademik yayın ortamına değerlendirme için gönderilmemiştir. $\mathrm{Bu}$ araştırmada doküman incelemesi yapıldığından etik kurul kararı zorunluluğu bulunmamaktadır.

\section{Kaynakça}

Aslan, K. (2004). Haber nasll okunur? İstanbul: Anahtar Kitaplar Yayınevi.

Aziz, A. (2013). Sosyal bilimlerde araştrma yöntemleri ve teknikleri. Ankara: Nobel Yayınlar1.

Balc1, A. (2013). Sosyal bilimlerde arastrtrma, yöntem, teknik ve ilkeler. Ankara: Pegem Akademi.

Belsey, A. ve Chadwick, R. (1998). Medya ve gazetecilikete etike sorunlar (Çev: N. Türkoğlu). İstanbul: Ayrıntı Yayınları.

Cengiz, A. ve Çağlar, Ş. (2003). Anlatı olarak haber. İstanbul Üniversitesi Iletişim Fakiultesi Dergisi, 18, 167-176.

Chomsky, N. (2012). Medya gerçeği (Çev: A. Yılmaz, O. Akınhay). İstanbul: Everest Yayınları.

Devran, Y. (2010). Haber söylemi ve ideoloji. İstanbul: Başılı Yayın Grubu.

Erdoğan, İ. (2005). İletisimi anlamak. Ankara: Erk Yayinevi.

Güz, N. (2005). Haberde yönlendirme ve kamuoyu arasstrmalarr. Ankara: Nobel Yayınları.

İnal, A. (1996). Haberi okumak. İstanbul: Temuçin Yayınları.

İrvan, S. (2014). Medya kïltür siyaset. Ankara: Pharmakon Yayınevi.

Küçük, M. (1999). Medya iktidar ideoloji. Ankara: Ark Yayınları.

Mora, N. (2004). Türk yazılı basınında haber anlayışı. İstanbul Üniversitesi Iletişim Fakültesi Dergisi, 19, 141-142.

Mutlu, E. (1995). İletisim sözliüü̈, Ankara: Ark Yayınları.

Oskay, Ü. (2014). Kitle iletisiminin kültuirel işlevleri. İstanbul: İnk1lap Kitabevi.

Özer, Ö. (2001). Haber söylem ideoloji: elestirel haber çözümlemeleri. Konya: Literatürk Yayınevi.

Özerkan, Ş (2002). Medya, dil ve ideoloji. İstanbul Üniversitesi İletisim Fakültesi Dergisi, 1(12), 63-76.

Rigel, N. (2000). İleti tasarmmnda haber. İstanbul: Der Yayınları.

Sözen, E. (1999). Söylem belirsiz̨lik, mübadele, bilgi/güc ve refleksivite. İstanbul: Paradigma Yayınları.

Uyguç, Ü. ve Genç, A. (1998). Radyo-televiryyon haberciliği. İstanbul: Avcıol Basım-Yayın.

Üşür, S. S. (1997). İdeolojinin serïveni. Ankara: İmge Kitabevi.

Van Dijk, T. A. (2003). Söylem ve ideoloji: Çok alanlı bir yaklaşım (Çev: N. Ateş) (Der: B. Çoban). Söylem ve ideoloji. İstanbul: Su Yayınevi.

Van Dijk, T. A. (2009). News, discourse, andideology. The bandbook of journalismstudies, 191-204. 
Van Dijk, T. A. (2015). Ideology.In G. Mazzoleni (Edt). The international encyclopedia of political communication. London: Wiley-Blackwell.

White, D. M. (1950). The 'GateKeeper': A casestudy in theselection of news. Journalismquarterly, 27, s.390 (çevrimiçi) http://www.aejmc.org/home/wpcontent/ uploads/2012/09/Journalism-Quarterly-1950-White-390.pdf, son erişim tarihi: 3 Nisan 2020.

\section{EXTENDED ABSTRACT}

Man wants to know what is happening in the society of which he is a member and in the world. The most important means of realizing this wish at the mass level is the mass media. Thanks to the speed and progress facilitated by scientific and technological development in the function of mass media, man's need for information has been met through very different channels and as quickly as possible. Individuals who are readers, listeners and viewers can reach almost instantly whatever they want to know thanks to the level of technological development today. Moreover, its cost has become very cheap, and the speed of access has increased greatly. However, the prevalence and speed of mass media, and the effect of the economy-politics of which they are a part in particular, have enabled them to go beyond giving only information and to undertake different functions. Mass media not only give information but also undertake the functions of "persuasion" and "manufacture of consent" on behalf of the economy-politics of which they are a part; furthermore, those functions have been essential in several aspects.

When it is evaluated from theoretical viewpoint, mass media have functions like giving news and information, entertaining, educating, moulding public opinion and checking political power on behalf of the public. "Persuasion" and "manufacture of consent" work in an articulated way with those functions. The relationships of mass media with local, national or global "powers" allow them to mutually legitimate each other; in this context, mass media attain a significant influence on the individual in particular and on the masses in general. However, the masses do not generally see or do not want to see the unconcealed relationships and functions in question. It would not be wrong to express this state as follows: Everybody sees that the king is naked, but nobody wants to say that he is "naked"; on the contrary, they prefer to mention the beauty of his non-existent clothes. The most important base for this determination is the existence of a widespread opinion that the mass media remain objective and act within the framework of professional ethics on behalf of the public in particular or their functions related to the public. However, many studies related to the field show that mass media are not only sources that provide news/information but they also play an active role in the political system and economic relations with their positioning in the face of the political power. The manufacture of "persuasion" and "consent" steps in at this stage and fulfils important functions because mass media present the message that they give to the masses with certain strategic methods in accordance with predetermined purposes by using the dynamic and highly developed technological infrastructure they have. The news presented to the target audience does not serve the purpose of informing only, but rather it aims to mould the audience into a certain form of thought.

This study is about the COVID-19 pandemic, which is on the agenda of the world public opinion as of December-2019 and which became a special problem in all countries in a short time. The COVID-19 pandemic has become one of the most important and even the only item on the agenda of mass media since the first case was seen on March 10, 2020 in Turkey. It is still like that in May 2020, when this article is being written. COVID-19 was among the news items of mass media in Turkey days and even months before it became high on the agenda of Turkey due to the cases in China, Iran, Italy, Spain and the USA, where tens of thousands of people died in total and a few thousand deaths were seen every day. It was expected that the pandemic would reach Turkey; therefore, measures were taken to delay it as mush possible and to lower the possible spreading speed of COVID-19. Official and civil initiatives, especially the state institutions and organizations, worked very hard to take measures against the pandemic. The state institutions and organizations acted earlier and were in the position of determining the process in terms of the extent and scope of the measures as expected. The unwanted but inevitable thing arrived on March 10 and the first case was officially detected. Thus, the COVID-19 pandemic became the only item on the agenda of mass media. It was seen in this agenda that mass media not only reported the COVID19 pandemic but also undertook the functions of informing the masses and raising awareness about the pandemic. They intensely fulfilled their functions of warning people about the magnitude of the danger and giving information about the measures to be taken. However, while doing so, they also tried to perform their function of supporting or criticizing by determining their positions in the face of the practices of the political power, which led the process. 
This research was made based on the headlines of the national newspapers in Turkey in the first ten days of the COVID-19 pandemic. The ideological positionings of the newspapers were tried to be determined through their discourses while performing the functions of support and/or criticism related to the practices of the political power in the hottest days of the agenda. To this end, the front-page news of 15 national newspapers between March 11-20, 2020 were examined. The newspapers forming the sample were the national newspapers called Takvim, Karar, Yeni Asir, Yeni Birlik, Türkiye, Yeni Akit, Cumburiyet, Yeni Safak, Aksam, Sözcü, Sabah, Hürriyet, Milliyet, Posta and Korkusu₹. The total circulation of those newspapers on March 15, 2020 was 1,736,111. The total daily circulation of national newspapers in Turkey is around 1.8 million. Thus, the circulation of those 15 newspapers forming the sample constitutes $97 \%$ of the total circulation of all national newspapers on the same day. 